\title{
A verdadeira e indispensável revolução brasileira
}

Estarrecidos, mulheres e homens de bem viram e ouviram notícias de que não se destinariam a uso (ensino e aprendizagem) milhões de livros didáticos novos e em perfeito estado de conservação (português, matemática, inglês, biologia) com o argumento espúrio de que estariam "desatualizados".

Ciência e Cultura se perpetuam no tempo, apesar de episódios lamentáveis de "queimas de livros" ou "censuras", até mesmo para que seja contada a magnífica e complexa História da Humanidade.

Fatos novos podem e devem ser acrescidos, a cada período (sem o descarte do anterior), decorrentes da criatividade humana que gere conhecimentos e/ou comprove a evolução de fenômenos/leis da Natureza como na Física (Aristóteles - Nicolau Copérnico - Galileu Galilei - Isaac Newton - Albert Einstein).

Mas esta avaliação deve pertencer a pessoas eticamente justas e muito bem formadas, cultural e cientificamente, sem viés ideológico e/ou uso oportunista de argumentos dogmático-religiosos.

Nada de bom se constrói para uma Sociedade Humana em que ainda viceja a ignorância manipulada e o analfabetismo que castra o acesso à informação de qualidade, o uso e o abuso que vivenciamos na divulgação de FAKE NEWS. E quem, eventualmente, financia sua veiculação deveria vir a ser enquadrado em "Crime de Lesa-Pátria", a partir da elaboração, aprovação e sanção de Norma específica, com punição rigorosa aos transgressores que enxovalham a construção e o amadurecimento da Cidadania.

Acredito ser imperioso começar a se refletir e a planejar criteriosamente nosso próximo voto, para que o processo eleitoral possa nos conduzir a governantes concretamente capazes de não apenas acenar com, mas verdadeiramente realizar, de forma célere e comprometida, enquanto PRIORIDADE NACIONAL, ações coordenadas que propiciem, na prática e em curto prazo, instalação e adequação de escolas civis públicas de qualidade para crianças e jovens, com recursos humanos e materiais necessários, além do imediato pagamento de piso nacional DIGNO para todos os profissionais de EDUCAÇÃO, desde a pré-escola. Reativar e intensificar cursos noturnos de alfabetização para adultos objetivando, paulatinamente, resgatá-los de grupos a quem não interessa que exerçam livre-arbítrio. Também conclamar mães e pais para cursos noturnos de reciclagem periódica em Ciências e Cultura.

Isto SIM seria democrático e revolucionário. Tornar realidade o sonho exequível do brilhante PAULO FREIRE (ensinar a ler e a escrever com base e conforme realidades locais e regionais, como, por exemplo: caqui e pêssego no sul; carambola e pitanga no nordeste). 
Nosso Brasil somente evoluirá como NAÇÃO quando este tempo de LUZ sobre as trevas chegar; com Social Democracia. Esta radicalidade inteligente eu apoio: escola pública de qualidade para TODOS.

\section{Marilia Gerhardt de Oliveira}

Professora e Pesquisadora

Cirurgiã e Traumatologista Bucomaxilofacial

Grupo Hospitalar Conceição - Porto Alegre - RS

Membro Titular da Academia Brasileira de Odontologia 